\title{
Aleksander Szwichtenberg
}

NOWE SPOJRZENIE NA ZAGOSPODAROWANIE PÓLWYSPU HELSKIEGO

LE REGARD NOUVEAU SUR L'AMÉNAGEMENT TOURISTIQUE DE LA PÉNINSULE DE HEL

\section{A NEW OUTLOOK ON THE TOURIST EXPLOITATION OF HEL PENINSULA}

Półwysep Helski jest wyjątkowym obszarem w Polsce. Część jego jest najmłodsza, jeszcze nie w pełni uformowaną geologicznie, przestrzenią w kraju, a jednocześnie dość intensywnie zagospodarowaną jest częścią parku krajobrazowego, co formalnie wyklucza turystykę masową, a jednocześnie terenem o najwyższym natężeniu ruchu turystycznego na całym polskim wybrzeżu.

W pracy przyjęto tezę, że półwysep ten będzie prawidłowo funkcjonował w przypadku gospodarowania jego walorami zgodnie z filozofią ekorozwoju. Opracowanie ma charakter ekspertyzy sugerującej zarówno nowy układ przestrzenno-funkcjonalny (koncepcja stratyfikacji zagospodarowania), jak również analizy ostrzegawczej. Ograniczenia i preferencje w rozwoju półwyspu określono $\mathrm{m}$. in. opierając się na wypowiedziach ekspertów, zwanych również w pracy sędziami kompetentnymi.

Celem tego opracowania jest więc przedstawienie koncepcji, która $\mathrm{z}$ jednej strony pozwoli ratować najbardziej zagrożoną część półwyspu, tj. północna, a $\mathrm{z}$ drugiej - przedkłada sposoby odnowienia gospodarczego (głównie turystycznego) części południowej wraz z miastem Hel.

W koncepcjach zagospodarowania Półwyspu Helskiego zakłada się, że podstawową funkcją gospodarczą winna być turystyka krajoznawcza i wypoczynek. Doświadczenia wynikające $\mathrm{z}$ kilkudziesięcioletniego użytkowania tego terenu wykazuja, że nie drugoplanowe funkcje (gospodarka morska, obronność kraju), 
ale właśnie szeroko rozumiana turystyka wraz z funkcją osadniczą, zresztą silnie stymulowaną przez funkcję turystyczną, stały się głównym zagrożeniem dla wartości półwyspu.

Przyjęto tezę, że odciążenie najbardziej narażonej na degradację części północnej, a także względne zbliżenie najatrakcyjniejszej części południowej do Trójmiasta, może nastapić poprzez zmianę środka transportu, tj. z samochodowego na wodny (rys. 1) i zwiększenie oferty usług turystycznych miasta Helu.
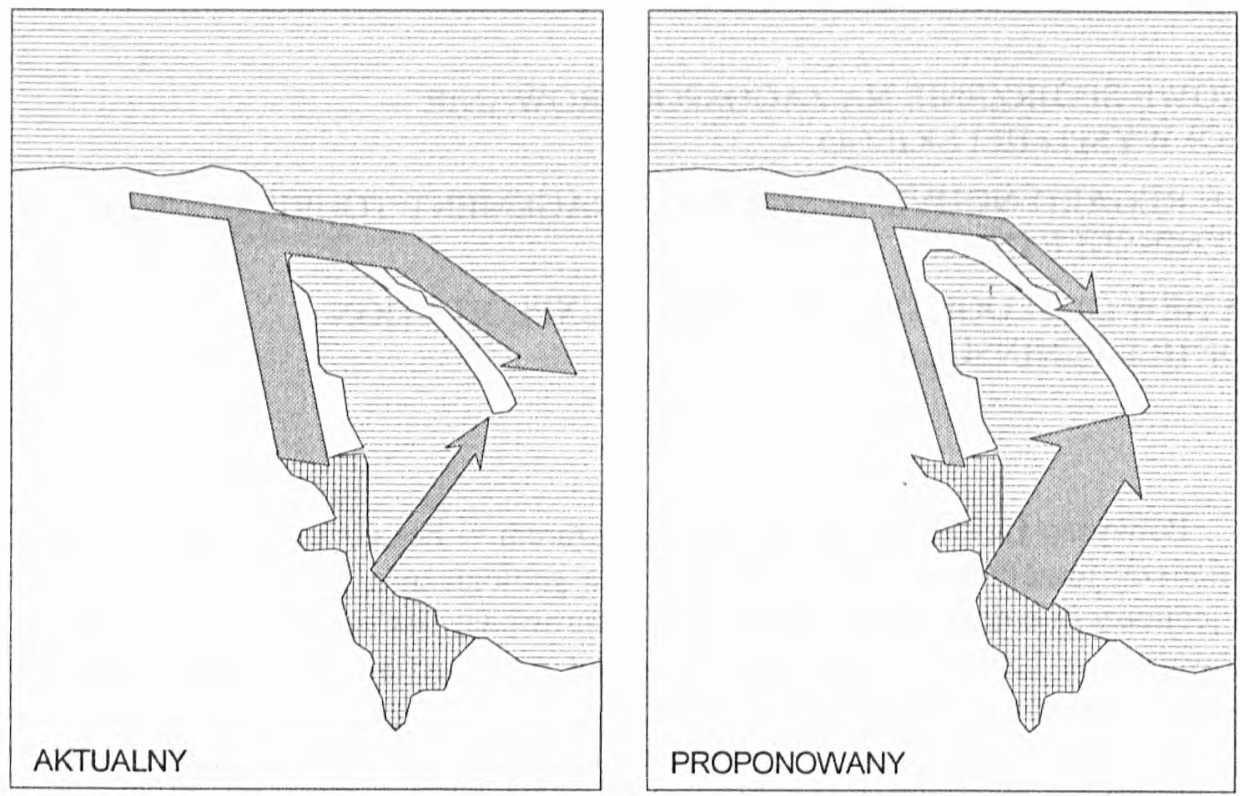

Rys. 1. Aktualny i potencjalny kierunek strumienia turystów zmierzających na Półwysep Helski

Dessin 1. La direction actuelle et potentielle du torrent des touristes allant vers la Péninsule de Hel

Zasadniczym celem tej koncepcji jest doprowadzenie do takiego przygotowania infrastruktury turystycznej i komunikacyjnej, aby penetracja półwyspu zaczynała się nie od północy, jak do tej pory, a od południa.

Liczne zmiany jakie nastapiły w ostatnich dwóch latach, m. in. „otwarcie” Helu i udostępnienie Zatoki Puckiej dla sportów wodnych, pozwalają na przyjęcie, umownie tutaj nazwanej, koncepcji stratyfikacji ekonomiczno-przestrzennej półwyspu. Celem jej jest wprowadzenie jak najwięcej form turystyki alternatywnej do części północnej, a także środkowej półwyspu (Chałupy, Kuźnica, Jastarnia i Jurata) i uaktywnienie gospodarcze miasta Helu.

Główny strumień turystów, szczególnie weekendowych, będzie napływał przede wszystkim z kierunku Trójmiasta. Należy zakładać, że będą oni korzystać z oferty półwyspu typu sea-sun-sand w niewielkim stopniu. Turyści trój- 
miejscy także nie będą preferować dwu lub kilkudniowych pobytów na mierzei ze względu na zbyt kosztowne usługi noclegowe. W efekcie można założyć, że będą to jednodniowe (niewykluczone, że jednonocne) wypady w poszukiwaniu rozrywki, którą głównie może im zapewnić odpowiednio przygotowany $\mathrm{Hel}$, w mniejszym stopniu - Jastarnia i Jurata.

Spodziewany wypoczynek świąteczny mieszkańców aglomeracji gdańskiej w minimalnym stopniu będzie oddziaływał na środowisko przyrodnicze, gdyż w małym stopniu będzie związany z walorami tego środowiska. Około $70 \%$ osób skorzysta z tzw. walorów antropogenicznych, a pozostała część - z przygotowanych atrakcji rekreacyjno-sportowych bądź plażowych. Sam przejazd różnymi środkami pływającymi będzie także jednym z elementów atrakcyjności tego typu eskapad.

Uwzględniając powyższe założenia przyjęto hipotetyczny kierunek rozwoju miejscowości Półwyspu Helskiego (rys. 2). Według tego wykresu Chałupy i Kuźnica winne rozwijać takie oferty turystyczne, które będą bazowały głównie na walorach środowiska przyrodniczego, wykorzystywanych w stopniu średnim. Dość niski stopień wykorzystania walorów wynika przede wszystkim z wyjątkowo dużej wrażliwości tego odcinka półwyspu na jakiekolwiek użytkowanie gospodarcze.

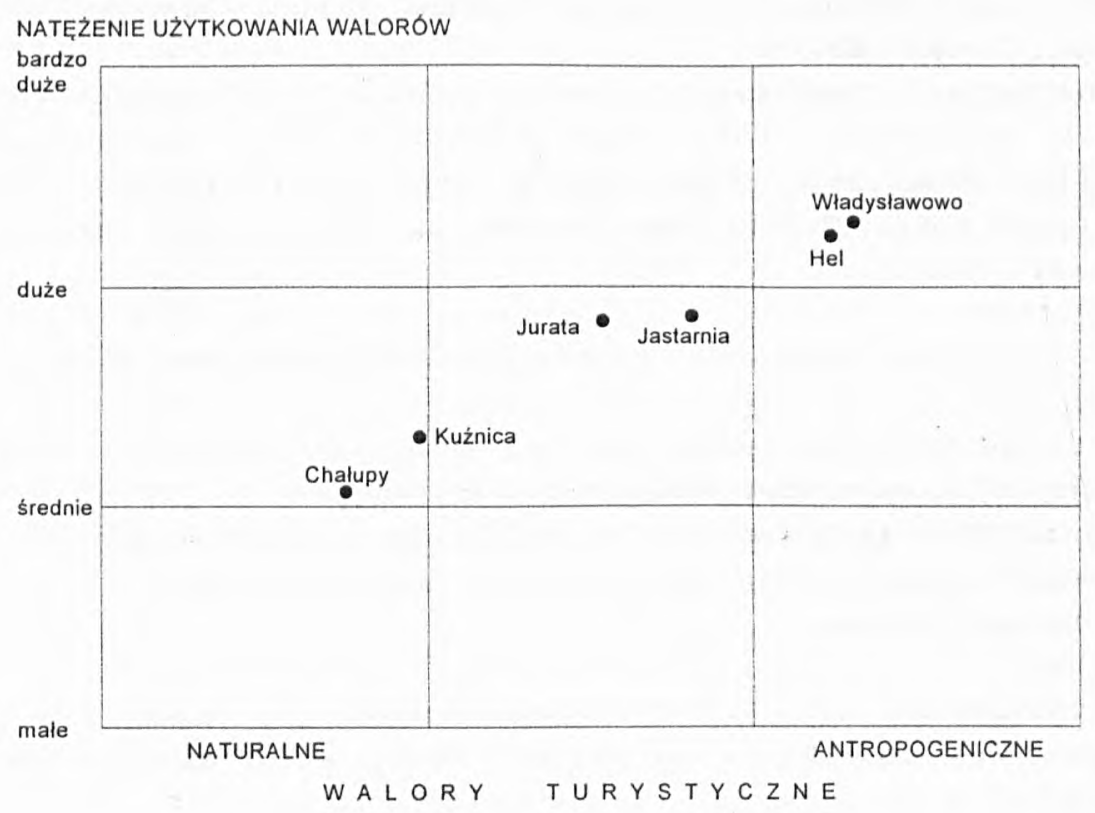

Rys. 2. Spodziewane kierunki rozwoju miejscowości Pólwyspu Helskiego

Dessin 2. Les directions attendues du développement des localités de la Péninsule de Hel 
Dla Helu, podobnie jak dla Władysławowa, najkorzystniejszym kierunkiem jest rozwój tych typów turystyki, które wymagają dużego zainwestowania, a jednocześnie są faworyzowane przez ludzi przedkładających rozrywkę i sport nad plażowanie i kapiele. Jastarnia i Jurata winne być nastawione na pośrednie parametry, a więc względnie duże wykorzystanie zarówno walorów turystycznych przyrodniczych, jak i antropogenicznych (rys. 2).

Z powyżej przedstawionego zróżnicowania wynikają istotne korzyści, a mianowicie: a) odciążenie części północnej półwyspu; b) „zbliżenie” części południowej do Trójmiasta poprzez polączenie wodne, szczególnie promowe; c) stworzenie całej gamy usług turystycznych (od najcichszych do najgłośniejszych, od najtańszych do najdroższych), ale takich, które nie kolidują z formami ochrony, jakimi jest objęty półwysep.

Analizując docelowe zagospodarowanie Półwyspu Helskiego należy pamiętać, że: a) część północna półwyspu, ze względu na nieustabilizowane warunki geologiczno-wodno-roślinne, wymaga najwięcej troski, a tym samym największych nakładów finansowych na jego zachowanie; b) koszty wjazdu na półwysep od strony Władysławowa, a także dość duże koszty samego przejazdu z Trójmiasta na półwysep z pewnością skłonią turystów do wyboru trasy wodnej; c) jedyny półwysep w Polsce nie może stać się ani terenem spędzania czasu dla elitarnych grup społecznych, ani też ściśle chronionym i zamkniętym. Proponowany wariant rozwoju zapewni pełną dostępność do półwyspu wszystkich kategorii i jednostek ludzkich.

Podstawowe kierunki zagospodarowania półwyspu i zatoki zostały określone $\mathrm{m}$. in. na podstawie wyników badań ankietowych przeprowadzonych przez autora tego opracowania w 1992 r. Sędziom kompetentnym, praktykom i teoretykom z zakresu geografii turyzmu przedstawiono trzy scenariusze rozwoju turystyki na tym terenie.

„Pierwszy”:

- zdecydowana i dość szybka eliminacja dużych i średnich ośrodków wczasowych,

- dążenie do przystosowania półwyspu głównie dla celów turystyki krajoznawczej (szlaki turystyczne, punkty widokowe, inne),

- maksymalne ograniczenie ruchu samochodowego na całym półwyspie,

- lokalizacja bazy hotelowej i parkingów u nasady półwyspu,

- inne ograniczenia.

„Drugi":

- wyłączenie z jakiegokolwiek zagospodarowania turystycznego i pozaturystycznego ok. jednej trzeciej powierzchni półwyspu i wód przybrzeżnych celem utworzenia stref ciszy,

- „odgospodarowanie” terenu półwyspu - bezwzględna eliminacja zakładów wczasowo-turystycznych substandardowych, nie spełniających aktualnie wymogów lokalizacyjnych, wodno-ściekowych, przeciwpożarowych, architektonicznych, 
- przeznaczenie części bazy wczasowo-wypoczynkowej na cele turystyki krajoznawczej,

- budowa minimum dwóch portów jachtowych w istniejących miejscowościach,

- sukcesywna eliminacja ruchu samochodowego na rzecz zintensyfikowania ruchu kolejowego i wprowadzenia regularnej żeglugi wzdłużbrzeżnej.

"Trzeci”:

- pozostawienie bazy turystyczno-wypoczynkowej na obecnym poziomie przy jednoczesnym dążeniu do podwyższania standardu obiektów, eliminacji konfliktów wewnętrznych (w ramach funkcji turystycznej) i zewnętrznych (funkcja turystyczna a inne funkcje gospodarcze),

- dążenie do przekształcenia obecnej bazy zakładowej na hotelową i pensjonatową,

- pełna komercjalizacja działalności turystycznej,

- budowa kilku baz jachtingowych typu marina,

- ruch samochodowy bez ograniczeń.

Wyniki sondażu wyraźnie wskazują, że nie jest wskazane przyjmowanie koncepcji skrajnych, tj. faworyzujących formy turystyki alternatywnej (wariant „pierwszy”) bądź tzw. przemysł turystyczny (wariant „trzeci”). Za „drugim” scenariuszem optowało $60 \%$ rzeczoznawców (tab. I). Większość ekspertów zdecydowanie opowiada się za wzrostem wymagań z zakresu ochrony przyrody i krajobrazu oraz eliminację obiektów substandardowych. Niżej zostaną przedstawione niektóre rozwiązania koncepcyjne w sposób bardziej szczegółowy, m. in.:

1) wyłączenie z jakiegokolwiek zagospodarowania turystycznego i pozaturystycznego minimum ok. jednej trzeciej powierzchni Półwyspu Helskiego i wód przybrzeżnych celem utworzenia stref ciszy;

2) „odgospodarowanie” obszaru półwyspu;

3) restrukturyzacja bazy noclegowej;

4) sukcesywna eliminacja ruchu samochodowego na rzecz zintensyfikowania ruchu kolejowego i wprowadzania regularnej żeglugi wzdłużbrzeżnej.

Ad 1. Założenie to ma pełne uzasadnienie wynikające $\mathrm{z}$ koncepcji ekologicznego rozwoju każdego regionu. Półwysep jest wyraźnie przeinwestowany. Świadczy o tym przede wszystkim znaczne przekroczenie pojemności turystycznej. Obliczenia wykazały, że w 1992 r. na obszarze półwyspu znajdowało się 21300 miejsc noclegowych, zaś pojemność przyjęta w planie Nadmorskiego Parku Krajobrazowego (Nadmorski Park..., 1980) wynosi zaledwie 17700 miejsc noclegowych. Około jednej trzeciej brzegów, liczących łącznie $72 \mathrm{~km}$, jest w zasięgu zainwestowania osadniczego i turystyczno-wczasowego (nie licząc zainwestowania militarnego), natomiast wszystkie polskie miejscowości nadmorskie położone do $5 \mathrm{~km}$ od linii brzegowej zajmuja jedynie $25 \%$ ogólnej długości linii brzegowej (S z w i c h t e n b e r g 1991). Podobna sytuacja jest 
w Anglii i Walii. J. A. Patmore (1972) podaje bowiem, ze z 2742 mil brzegów, $25 \%$ jest zainwestowanych. Na $62,5 \%$ wybrzeży angielskich i walijskich dąży się do zapobiegania powstawaniu nowych inwestycji.

Tabela I

Opinie 35 ekspertów dotyczące zagospodarowania turystycznego Pólwyspu Helskiego (w \%)

Les opinions des 35 experts concernant l'aménagement touristique de la Péninsule de Hel (\%)

\begin{tabular}{|c|c|c|c|}
\hline \multirow[b]{2}{*}{ Problem } & \multicolumn{3}{|c|}{ Odpowiedzi } \\
\hline & tak & nie & $\begin{array}{l}\text { nie mam zdania, } \\
\text { brak odpowiedzi }\end{array}$ \\
\hline $\begin{array}{l}\text { 1. Półwysep Helski powinien stanowić samodzielnąjednostkę } \\
\text { przestrzenną (samodzielny subregion gospodarczy i samodziel- } \\
\text { nąjednostkę samorządową) }\end{array}$ & 62,9 & 22,8 & 14,3 \\
\hline $\begin{array}{l}\text { 2. Działalność gospodarcza na Półwyspie Helskim winna o- } \\
\text { pierać się tylko na małych i średnich rodzinnych zakładach tury- } \\
\text { stycznych, rzemieślniczych i usługowych }\end{array}$ & 68,6 & 17,1 & 14,3 \\
\hline $\begin{array}{l}\text { 3. Celem ochrony środowiska przyrodniczego Półwyspu Hel- } \\
\text { skiego i poprawy warunków życia oraz wypoczynku należałoby } \\
\text { ograniczyć dostęp ludności stałej i turystów na ten teren przez: } \\
\text { - zwiększone opodatkowanie obrotu nieruchomościami, } \\
\text { - podwojenie podatków dla zakładów rzemieślniczych i turysty- } \\
\text { cznych średnich i dużych, } \\
\text { - wyłączenie z użytkowania najcenniejszych z punktu widzenia } \\
\text { przyrodniczego terenów celem utworzenia stref ciszy, } \\
\text { - wstrzymanie budowy obiektów na terenach najcenniejszych } \\
\text { z punktu widzenia przyrodniczego, } \\
\text { - sukcesywne zmniejszanie powierzchni terenów przeznaczo- } \\
\text { nych pod budownictwo i infrastrukturę komunikacyjną } \\
\text { - zastosowanie środków zniechęcających do korzystania z sa- } \\
\text { mochodów }\end{array}$ & $\begin{array}{l}45,7 \\
28,6 \\
71,4 \\
62,9 \\
51,4 \\
40,0\end{array}$ & $\begin{array}{r}11,4 \\
22,8 \\
5,7 \\
5,7 \\
5,7 \\
20,0\end{array}$ & $\begin{array}{l}42,9 \\
48,6 \\
22,9 \\
31,4 \\
42,9 \\
40,0\end{array}$ \\
\hline $\begin{array}{l}\text { 4. Schematyczne scenariusze rozwoju ekoturystyki, za który- } \\
\text { mi optowali eksperci: } \\
\text { „pierwszy" } \\
\text { "drugi" } \\
\text { "trzeci" }\end{array}$ & $\begin{array}{l}11,4 \\
62,9 \\
25,7\end{array}$ & & \\
\hline
\end{tabular}

Ź r ó d ł o: Badania wlasne.

Przy uwzględnieniu trzech kryteriów, a mianowicie: a) jakości walorów krajobrazowych; b) odporności elementów środowiska przyrodniczego na degradację oraz c) możliwości zachowania zrównoważonego układu ekologicznego, wyróżniono dwa obszary, które winny być wyłączone z jakiegokolwiek zagospodarowania. Są to:

a. Tereny między parkingami strategicznymi, położonymi przy nasadzie pólwyspu, a kempingiem „Małe Morze”. Leżący między drogą helską a Zatoką 
Pucką jest rzadko porośnięty samosiewami sosny, jarzębiny i kępami dzikiej róży. Darń, składająca się z traw i większych kęp wrzosów, jest wyjątkowo wrażliwa na wydeptywanie. Teren ten winien być w pierwszej kolejności zalesiony.

b. Kompleks roślinności łąkowo-bagiennej w okolicy Jastarni, przewidywany jako potencjalny rezerwat ornitologiczny. Należy podjąć prace nad jego granicami, a także analizą fitosocjologiczną. Potencjalny rezerwat może stać się magnesem dla określonej grupy turystów, sympatyków watchingu - obserwowania ptactwa wodnego.

Oba te obszary są w dużym stopniu narażone przez nadmierne wydeptywanie, jak również silną presję inwestycyjną.

Zgodnie $\mathrm{z}$ obowiązującym ustawodawstwem, w lasach udostępnionych przez wojsko (między Jurata a Helem) może być prowadzona normalna gospodarka leśna, łącznie z dokonywaniem zrębów zupełnych. Położenie tego kompleksu leśnego na jedynym polskim półwyspie, jego specyficzny charakter ochrony winny spowodować, że zostanie on wyłączony z administracji lasów państwowych i przeznaczony na rezerwat. Ponad $71 \%$ respondentów uznało, że tworzenie terenów rezerwatowych na Półwyspie Helskim jest postępowaniem słusznym (tab. I). Także ok. 63\% ekspertów podziela pogląd, że należy wstrzymać budowy obiektów położonych na terenach najcenniejszych z punktu widzenia przyrodniczego, w tym na trzech wyżej wymienionych obszarach (tab. I).

Ad 2. Proces „odgospodarowywania” Półwyspu Helskiego jest konieczny. Około $39 \%$ tego obszaru zajmują tereny zainwestowania cywilnego, pięć miejscowości zajmuje bowiem aż 1216 ha. Ponadto znaczna część bazy na jego terenie ma charakter substandardowy. Odnosi się to zasadniczo do trzech miejscowości, a mianowicie: Jastarni, Juraty i Helu. Modernizacji powinny ulec przede wszystkim: Ośrodek Wczasów Wagonowych PKP w Jastarni (ul. Ogrodowa 170), a także osiem mniejszych ośrodków kempingowych przy ul. Ogrodowej, Bałtyckiej i Leśnej. To właśnie Rada Miejska winna rozważyć, czy tak cenny teren może być w nieracjonalny sposób wykorzystany. Nieco wyższy standard reprezentują ośrodki, posiadające kempingi w Juracie. Jednak i tamte obiekty należy rewaloryzować i przystosowywać do dłuższego czasu eksploatacji.

Pod hasłem „odgospodarowywania” należy rozumieć również dążenie do realizacji inwestycji wg zasad architektonicznych właściwych dla Nadmorskiego Parku Krajobrazowego. Nastawienie na zyski płynące z turystyki doprowadziły m. in. do budowy domów-klocków, zwanych przez mieszkańców „byksami”, w których można było wygospodarować jak najwięcej pokoi dla letników. Architekci w pełni wówczas zaakceptowali ten styl. Typowym przykładem wspomnianych działań może być część Kuźnicy zwanej Syberią i większość powojennych domów na całym półwyspie. Widocznie wyraźny proces ubożenia mieszkańców tego terenu nie pozwala na proces modernizacyjny. Jedyny obiekt w Jastarni, nawiązujący w pełni do kaszubskich tradycji budowlanych, został zbudowany w Jastarni przy ul. Mickiewicza (zakład szkutniczy Pana Budzisza). 
Jastarnia jest przykładem miejscowości pozbawionej ładu przestrzennego. Przede wszystkim brak w niej centrum. Główną przeszkodą na drodze wygospodarowania terenów ogólnodostępnych jest fakt, że 95\% gruntów miasta znajduje się w rękach prywatnych. Jest to jednak ograniczenie pozorne. Miasto winno zastosować określone instrumenty ekonomiczne. Między innymi właściciele gruntów będą mogli uzyskać dochody zarówno jako współudziałowcy promenady wraz z pasażem usługowo-handlowym (projektowanej w Koncepcji zagospodarowania przestrzennego centrum Jastarni, 1980), jak też jako dzierżawcy gruntu bądź wybudowanych obiektów przy „promenadzie północ-południe”.

Dwie decyzje podjęte w latach dziewięćdziesiątych przez wojsko należy uznać za wyjątkowo korzystne dla rozwoju turystyki na badanym obszarze. $Z$ jednej strony przywrócono całą Zatokę Pucką dla żeglugi jachtowej i innych sportów wodnych, a z drugiej - udostępniono prawie wszystkie odcinki plażowe od strony morza i zatoki. Także niektóre obiekty turystyczne do tej pory zamknięte dla osób cywilnych zostały częściowo udostępnione od 1922 r. Uznając zasadność dalszego dysponowania przez wojsko znacznymi terenami półwyspu, należy podkreślić nieracjonalność wykorzystania niektórych jego fragmentów. Szczególnie dwóch działek (28UT i 35UT - wg planu Nadmorskiego Parku Krajobrazowego) o łącznej powierzchni ok. 5 ha, położonych w sąsiedztwie Helu, które pozwoliłyby na częściowe rozwiązanie problemów zagospodarowania przestrzennego tego miasta.

Nakazowa likwidacja obiektów turystycznych, nie spełniających wymogów budowlanych, architektonicznych, przeciwpożarowych, wodnoprawnych i innych, nie zdała egzaminu. Chociaż w minionych latach wydano wiele nakazów ich likwidacji, prawie wszystkie pozostały, zgodnie z filozofią - nie należy ograniczać światu pracy dostępu do „godziwego” wypoczynku. Porządkowanie bazy turystycznej i przestrzeni całej gminy winno odbywać się wg wzorów przyjmowanych na Zachodzie, poprzez stosowanie ulg podatkowych, opłat, licencji itd. (tzw. ekonomiczna treść planu). Propozycja zwiększenia opodatkowania obrotu nieruchomościami uzyskała akceptację zaledwie $45,7 \%$ wypowiadających się ekspertów (tab. I). Podobnie niską akceptację ekspertów uzyskała propozycja podwojenia podatków dla zakładów rzemieślniczych i turystycznych średnich oraz dużych, tj. tych, które są najagresywniejsze wobec terenów Nadmorskiego Parku Krajobrazowego. Prawie $70 \%$ wypowiadających się ekspertów jest zdania, że działalność gospodarcza na Półwyspie Helskim winna opierać się tylko na małych i średnich (rodzinnych) zakładach turystycznych, rzemieślniczych i usługowych.

Na Półwyspie Helskim, charakteryzującym się wysokimi walorami i małą odpornością, należy prowadzić tzw. politykę średniej miary (K r i p pe n d o r f 1986). Polega ona na konsekwentnym popieraniu małych i średnich zakładów rodzinnych. Wielkie ośrodki zawsze będą własnością instytucji lub osób prywatnych spoza półwyspu. $Z$ właściwym podejściem do walorów przyrodni- 
czych i społeczności lokalnèj będzie można liczyć się wtedy, gdy interesy ludności miejscowej będą w' pewnym sensie uprzywilejowane, gdy małe rodzinne pensjonaty i hotele będą liczbowo przeważały nad bazą noclegową wczasowo-wypoczynkową w obecnym kształcie. Ich właściciele szybko i skutecznie reagują na zmieniający się rynek, dostosowują się do gustów gości poprzez zmianę cen w zależności od popytu.

Ad 3. Na zmianę struktury bazy noclegowej na Półwyspie Helskim pozytywny wpływ mają zjawiska zapoczątkowane w 1991 r., do których należy proces przekształceń własnościowych w Jastarni i Juracie. Między innymi sprzedane zostały dwa duże ośrodki byłej PZPR, tj. OW „Neptun” (82 pokoje) oraz OW „Bryza” (80 pokoi) - obydwa w Juracie. Na przetarg wystawiono także obiekty należące do FWP Olsztyn (48 pokoi) w Juracie. Oferty sprzedaży, dzierżawienia bądź utworzenia spółki zgłosili również inni właściciele, jak np. Ministerstwo Zdrowia i Opieki Społecznej Warszawa - OW „Wielkopolanka” i OW „Marysieńka" w Juracie (260 miejsc), Rudzkie Gwarectwo Węglowe Kopalnia „Pokój” w Rudzie Śląskiej - OW „Posejdon” (250 miejsc).

Sprzedaż pierwszych trzech wspomnianych obiektów, należących do Skarbu Gminy, w zasadniczy sposób poprawiło kondycję finansową tej jednostki samorządowej. Uzyskane środki pomogły bowiem $\mathrm{w}$ realizacji inwestycji z zakresu gospodarki komunalnej.

Istotnym zagadnieniem z zakresu gospodarki przestrzennej Półwyspu Helskiego stanowią kempingi i pola namiotowe. $Z$ powodu braku terenu ich liczba powinna pozostać bez zmian, tj. siedem obiektów dużych i kilka bardzo małych, przydomowych. Nie mogą one jednak istnieć w takim stanie jakościowym, jak obecnie. Półwysep Helski jest zbyt ekskluzywnym terenem, aby w dalszym ciągu przeznaczać go pod usługi niskiej jakości, jak np. na obecnych polach namiotowych. Dwa obiekty, „Maszoperia” i „Kaper”, stały się bazą dla sympatyków windserfingu. Chociaż sport ten rozwija się na zatoce od zaledwie dwóch lat, staje się bardzo widoczną formą spędzania czasu. W pierwszym z wymienionych kempingów w 1992 r. ok. 30-40\%, zaś w drugim - 60\% (w tym połowa spoza kraju) uczestników uprawiała sporty wodne, szczególnie windserfing.

Zatoka Pucka poprzez swoją płytkość, silne wiatry i dość ciepłą, a także w miarę czystą wodę ma najdoskonalsze w Polsce morskie warunki do uprawiania tego sportu. Wizja lokalna wykazała jednak, że brzegi w najwyższym stopniu zostały zniszczone na odcinkach obu kempingów, gdzie linia brzegowa przesunęła się w kierunku lądu miejscami o 3-4 m. Chociaż projektanci planu Nadmorskiego Parku Krajobrazowego podkreślają że obiekty kubaturowe kempingów powinny uwzględniać formy architektury regionalnej, w żadnym przypadku tak się nie dzieje. Dzierżawcy (wszystkie tego typu obiekty zostały przekazane przez Urzędy Miejskie w pięcioletnią dzierżawę) wg własnego uznania próbują realizować różnego typu inwestycje. Taka polityka jest absolutnie nie do przyjęcia. 
Ad 4. B. W a n d t k e (1992) obliczył, że w szczycie świątecznym na Półwyspie Helskim porusza się ok. 5 tys. samochodów. Wszystkie miejscowości tego półwyspu, szczególnie Chałupy, Kuźnica i Jurata mają charakter zabudowy typowej „ulicówki”. Ruch samochodowy nie jest więc obojętny ani dla środowiska przyrodniczego, ani też dla istniejących bądź potencjalnych form turystyki, szczególnie alternatywnej. Poglądy ekspertów na temat zastosowania ewentualnych środków zniechęcających do korzystania z samochodów na obszarze półwyspu są dość zróżnicowane (tab. I). Około 40\% spośród nich jest zdania, że należy: a) wprowadzić specjalne opłaty drogowe, b) stosować obowiązkowe wysokie oplaty parkingowe, bądź c) przyjąć zakaz poruszania się samochodów osobowych, oprócz komunikacji miejscowej. Obostrzenia te absolutnie nie dotyczyłyby ludności stałej. Wielu spośród ankietowanych proponuje wrócić do zainstalowania rogatek u nasady półwyspu celem pobierania wysokich opłat za wjazd samochodem.

Autor niniejszego opracowania proponuje następujące rozwiązania pozwalające na całkowite lub częściowe wyeliminowanie osobowego ruchu samochodowego: a) budowa portów bądź modernizacja istniejących celem uaktywnienia komunikacji wodnej; b) rozbudowa portów jachtowych na wzór zachodnich marin; c) elektryfikacja istniejacej linii kolejowej; d) wprowadzenie innych form poruszania się w obrębie półwyspu.

Analiza połączeń wodnych miejscowości Półwyspu Helskiego z Trójmiastem wykazała, że winna być zwiększona częstotliwość połączeń, a także należy wprowadzić rejsy nocne i skorelować kursy statków z rozkładem jazdy pociągów. A. J o n e s (1990) badając problemy rentowności turystyki na wyspie Bardsey (północna Walia) doszedł do wniosku, że o jej lepszej kondycji zadecydował $\mathrm{m}$. in. zwiększony dostęp dla zwiedzających dzięki regularnym kursom statków. A priori należy zakładać, że tańszy będzie bilet na jakąkolwiek jednostkę pływającą niż koszty samego przejazdu samochodem osobowym z Trójmiasta na półwysep w połączeniu z wysokimi opłatami parkingowymi i drogowymi na samym półwyspie. Powodzenie tej inicjatywy zależeć będzie od tego, czy zostanie przyjęty przez samorządy lokalne zaproponowany wariant rozwoju Półwyspu Helskiego (rys. 1).

Systematycznie malejące dochody mieszkańców półwyspu z rybołówstwa winne skłonić właścicieli kutrów i łodzi motorowych do włączenia się w obsługę ruchu turystycznego. Mogą to być zarówno linie regularne, jak też dostosowane do potrzeb określonych grup turystów, np. zwolenników autentycznych połowów morskich. Określonych nakładów wymaga przystosowanie jednostek pływających, szczególnie celem zapewnienia bezpieczeństwa (koła ratunkowe, kapoki itd.). Tego typu oprzyrządowanie można jednak zakupić zespołowo bądź ze środków gminnych, przeznaczonych na aktywizację zawodową regionu. Część rybaków, z którymi przeprowadzono wywiad, uznała powyższy pomysł za słuszny. Obawy ich dotyczyły głównie systemu podatkowego, który - jak twierdzą - nie pozwoli na właściwe rozwinięcie tej inicjatywy. 
Lokalna przedsiębiorczośc przede wszystkim powinna doprowadzić do rozkwitu portów jachtowyeh. Obecnie w Polsce są tylko trzy z prawdziwego zdarzenia porty jachtowe, które są zdolne obsługiwać międzynarodową turystykę jachtową (Trzebież, Kołobrzeg, Gdynia). Porty rybackie Półwyspu Helskiego winno się sukcesywnie przekształcać w mariny, posiadające odpowiedni tor wodny o głębokości odpowiedniej dla jachtów morskich, baseny, wypożyczalnie sprzętu, hangary, warsztaty, punkt aprowizacji wody itd. Sa to inwestycje bardzo kosztowne, stąd też samorządy lokalne winny ten problem rozwiązać poprzez powoływanie fundacji lub w ramach istniejącego Związku Gmin. Szczegółowa analiza stosunków własnościowych i możliwości adaptacyjnych portów helskiego i jastarniańskiego, przeprowadzona przez autora opracowania, wykazała, że mogą się one w krótkim czasie stać portami jachtingowymi z prawdziwego zdarzenia. Pierwsze prace w tym kierunku zostały podjęte.

Celem pelnego zaktywizowania dwóch wyżej wymienionych portów, a także istniejącego we Władysławowie, należy w jak najszybszym czasie uregulować następujące sprawy formalnoprawne: a) doprowadzić do porozumień międzyresortowych powodujących, że otwarty już port jachtowy w Helu będzie mógł przyjmować także jednostki zagraniczne; b) zmienić przepisy prawne, wg których baseny portowe będące własnością przedsiębiorstw połowowych ( $\mathrm{Hel}$ „Korab”, Władysławowo - „Szkuner”) staną się własnością komunalną; c) rozwiązać paradoksalną sytuację występująca w Jastarni i Helu. W pierwszym przypadku dysponentem basenu portowego jest Urząd Morski, do którego obowiązków należy kontrola tego typu obiektów morskich. Natomiast w Helu Urząd Miejski aby uruchomić przystań jachtową, musiał dzierżawić ziemię i część basenu rybackiego od upadającego przedsiębiorstwa „Korab”.

Wyjątkowe natężenie ruchu samochodowego na Półwyspie Helskim było przyczyna, że od czerwca 1983 r. do czerwca 1991 r. obowiązywała uchwała o ograniczeniu ruchu pojazdów mechanicznych i regulowanym poruszaniu się na tym terenie. Dziewięcioletnie doświadczenia były pozytywne, szczególnie dla środowiska przyrodniczego. Samorządy zadecydowały inaczej. Szukanie natychmiastowych źródeł dochodu, poprzez m. in. zwiększenie dostępu turystów na teren półwyspu, jest polityką krótkowzroczną. Do tej pory nie zostały przedstawione inne rozwiązania.

Za przedstawioną koncepcją stratyfikacji zagospodarowania Półwyspu Helskiego przemawia, oprócz korzyści przedstawionych wcześniej, także problem odciążenia trasy kołowej Reda-Władysławowo. Trasa z Gdyni do Helu jest jedną z trudniejszych w Polsce, szczególnie na odcinku wyżej wymienionym. Koszty modernizacyjne mogłyby być przeznaczone na zakup taboru pływającego. Problem wymaga głębszej analizy. Już teraz można jednak przyjąć tezę, że władze województwa gdańskiego nie będą w stanie wygospodarować funduszy na wybudowanie drugiego pasma. Nie może być także przedsiębrana jakakolwiek koncepcja poszerzenia drogi helskiej, chociaż jest wąska i niebezpieczna, szcze- 
gólnie dla pieszych i rowerzystów, Jedynym słusznym i właściwym kierunkiem rozwiązania tego problemu jest budowa trasy rowerowej $z_{0}$ Władysławowa do Juraty. W tym celu należy wykorzystać istniejące fragmenty dawnej drogi helskiej, biegnącej bliżej linii brzegowej. Droga ta jest dość dobrze zachowana.

Tętniące do niedawna życiem tzw. parkingi strategiczne, położone u nasady półwyspu, obecnie zarastają. Koniecznie należy wrócić do zaniechanej w $1991 \mathrm{r}$. ustawy o pełnej dostępności półwyspu dla pojazdów samochodowych. Koncepcja ta musi jednak być udoskonalona. Przede wszystkim przystanek PKP Władysławowo Port winien być podczas sezonu przeniesiony o $700 \mathrm{~m}$, na miejsce przystanku Wielka Wieś (istnieje on tylko na mapach 1:25000), usytuowanego tuż obok wspomnianych parkingów.

\section{PIŚMIENNICTWO}

J o n e s A., 1990, Alternatywne ujęcie rozwoju turystyki na przykladzie Walii, „Problemy Turystyki", $\mathrm{nr} 3 / 4$.

K r i p p e n d o r f J., 1986, Nieskażona przyroda jako podstawa istnienia turystyki, „Problemy Turystyki", nr $3 / 4$.

Nadmorski Park Krajobrazowy - plan generalny, 1980, BPP, Gdańsk:

P a $\mathrm{t} \mathrm{m}$ o r e J. A., 1972, Land and Leisure, Penguin Books, London.

S z w i c h t e n b e r g A., 1991, Stymulatory $i$ bariery rozwoju funkcji turystycznej w polskiej strefie nadbattyckiej, Koszalin.

W a n d t k e B., 1992, Opinia w sprawie ratowania Pólwyspu Helskiego oraz przeciwdziatania degradacji środowiska przyrodniczego i jego walorów krajobrazowych, Materiał powielony, Sopot.

Prof. dr hab. Aleksander Szwichtenberg

Katedra Geografii

Wpłynęło:

Wyższa Szkoła Pedagogiczna

ul. Arciszewskiego 226

76-200 Slupsk 